Historic, archived document

Do not assume content reflects current scientific knowledge, policies, or practices. 
Dear Sir:

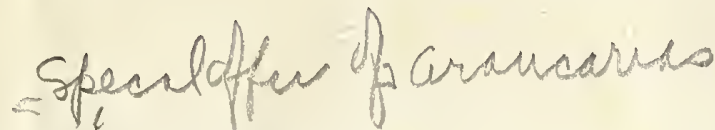

We beg to call your attention to some exceptional values in Araucarias which we offer below。

These plants are all growing in the open air in slat houses, are perfect, healthy, of good color and well furnished, and, as there are more than we can conveniently make room for indoors, we make this low offer for immediate acceptance and delivery.

Note sizes and measurements and compare same to what you have purchased before and you will quickly realize the exceptional value of this stock.

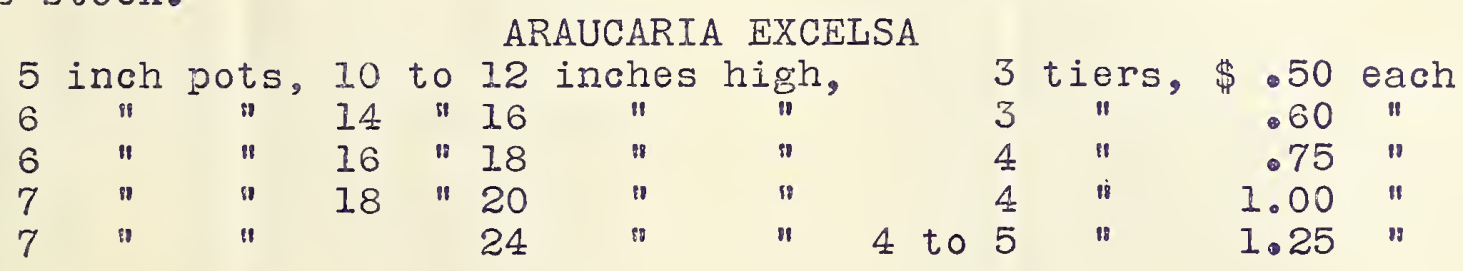

ARAUCARIA EXCELSA GLAUCA
5 inch pots, 10 inches high, 2 to 3 tiers, "⿻ 60 each
6 " 12 to 14 "

ARAUCARIA ROBUSTA COMPACTA

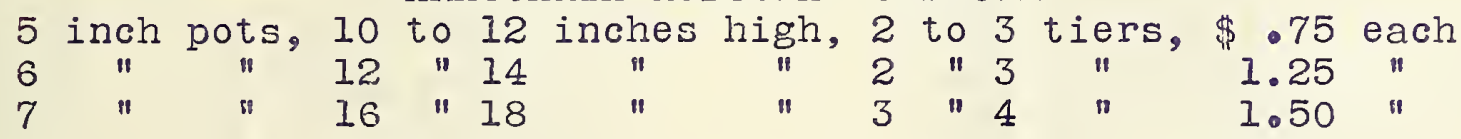

ARAUCARIA EXCELSA PLUMOSA

A rare variety, similar in habit to Araucaria Robusta Compacta but with very deep green foliage; very desirable.

6 inch pots, 12 to 14 inches high, 3 tiers, \$.75 each

\section{PTERIS WILSONI}

We have, during the past four years, been growing a lot of this beautipul crested Pteris into siz-inch pans which sold on sight and our supplies were quickly exhausted. This season we have an exceptionally fine lot in six-inch pans which we offer at $35 \mathrm{c}$ each. We also have a splendid lot of 2-1/4-inch pot plants of the same variety at $\$ 3.50$ per hundred; $\$ 30.00$ per thousand.

Yours very truly,


In ordering please refer to Circular No. 76. 
